\title{
A Study on the Predictors of Success and Satisfaction in an Online Higher Education Program in Turkey
}

\author{
Özkan Kirmizi ${ }^{1, *}$ \\ ${ }^{1}$ Karabuk University, Department of English Language and Literature, Turkey \\ *Correspondence: Department of English Language and Literature, Karabuk University, \\ Turkey. E-mail: ozkankirmizi@karabuk.edu.tr
}

Received: July 25, $2014 \quad$ Accepted: August 26, $2014 \quad$ Published: October 27, 2014

doi:10.5296/ije.v6i4.6322 URL: http://dx.doi.org/10.5296/ije.v6i4.6322

\begin{abstract}
The aim of this study was to determine the predictors of success and satisfaction in an undergraduate distance education ELL degree program in Turkey. In this study, the independent variables are instructor support, student interaction and collaboration, personal relevance, authentic learning, active learning, and student autonomy and the dependent variables are student success and student satisfaction. The participants were 85 distance education students enrolled at the English Language and Literature Distance Education Program at Karabük University. In order to collect data, Education Learning Environment Survey (DELES), developed and validated by Walker and Fraser (2003), was used. This survey includes six psycho-social scales: 1) instructor support, 2) student interaction and collaboration, 3) personal relevance, 4) authentic learning, 5) active learning, and 6) student autonomy. In order to ascertain the relation between the variables, a correlation analysis was carried out. A moderate level of correlation was observed among the variables of the study. In addition, two regression tests were administered in order to measure the influence of the independent variables on both success and satisfaction. The results indicate that the predictors of student satisfaction are instructor support, authentic learning, and personal relevance, whereas the only strong predictor of academic success was authentic learning.
\end{abstract}

Keywords: Instructor support, Student interaction, Collaboration, Personal relevance, Authentic learning, Active learning, Student autonomy 


\section{Introduction}

As online programs proliferate every day as a result of the advances in technology, more institutions design distance education programs. Therefore, student achievement and student satisfaction are crucial issues that must be studied carefully in order to provide betterment for online courses. Although some researchers think that there are not significant differences between online learning and traditional face-to-face classroom learning in terms of learning outcomes (Allen, Bourhis, Burrell \& Mabry, 2002), student satisfaction in online learning still remains an important issue on account of the fact that new technologies have altered the way that students interact with instructors and classmates (Kaminski, Switzer, \& Gloeckner, 2009).

Another important issue for online programs is student achievement. Some researchers believe that students who succeed in traditional settings may not do well in online courses. The reasons for this may range from students motivation, self-discipline to any other learner characteristics. Therefore, there is a need to investigate learner achievement in online education programs in relation to various factors. The purpose of this study is to investigate student success and satisfaction in a distance education program in relation to instructor support, student interaction and collaboration, personal relevance, authentic learning, active learning, and student autonomy.

\section{Review of Literature}

\subsection{Academic Success in Distance Education}

The need for researching the factors that affect student success in distance education courses was voiced decades ago (Biner et al., 1996; Dille \& Mezak, 1991; Stone, 1992). The literature includes studies that focus on the factors that contribute to success. However, most of them are rather inconclusive and the factors have not been accurately described (Phipps \& Merisotis, 1999). The factors that have been investigated in relation to success in distance education are age, educational level, locus of control, learning style, motivational beliefs, and self-regulated learning components.

First of all, although there are conflicting views, studies that focus on age and success in distance education programs found that the average age of successful students was 28 rather than 25 (Dille and Mezack, 1991). There are also some studies that do not find any significant relation between age and success in distance education programs (Biner et al, 1996). Another factor in relation to success was locus of control. Studies that boiled down to locus of control generally found that students with an internal locus of control are more likely to be successful than students with an external locus of control (Dille \& Mezack, 1991; Parker, 1999; Stone, 1992). Another line of research focused on learning styles and success in distance education programs. A large number of studies have been conducted in this regard, but the results are rather conflicting. Loomis's (2000) study found that learning styles are influential in success in distance education programs while studies carried out by Shih \& Gamon (2001) and Wang et al., (2001) found no relation between success and learning styles. 
A number of studies have been carried out in Turkish context that investigated success in relation to a number of different variables. Yükseltürk and Bulut (2007), for example, worked on success in relation to a number of variables such as motivational beliefs (intrinsic goal orientation, extrinsic goal orientation, control beliefs, task value, self-efficacy, and test anxiety), self-regulated learning components (cognitive strategy use, self-regulation), and student success in the online course. Their study found that among the other variables the impact of self-regulation on students' success was statistically significant, and the interview results indicated that successful students generally used self-regulated learning strategies in the online course. In another study, Tok, Özgan, and Döş (2010) investigated student success in relation to metacognitive awareness and learning strategies. Their study found that there was a strong correlation between metacognitive awareness, learning strategies and students' academic success in an online English course. In another similar study, a positive and significant correlation was found between learning strategies and the level of academic performance (Simsek and Balaban, 2010)

In addition, success was also studied in relation to motivation in distance education and it is considered one of the most important predictors of success. Students' level of motivation was found to be a critical factor for successful online education (Keller, 1999; Sankaran \& Bui, 2001; Song, 2000). Another important variable that was studied in terms of its contribution to success in distance education is self-regulated learning. Research on self-regulated learning indicates a strong relationship between students' academic success and the use of self-regulated learning strategies (Zimmerman, 2002; Zimmerman \& Martinez-Pons, 1990).

To conclude, we can understand from the literature that academic success has been studied extensively in relation to various factors like age, locus of control, self-regulated learning, and motivation. Although there are conflicting results, most of the studies on academic success in distance education found significant relationships between the stated variables and academic success (Yükseltürk \& Bulut, 2008). However, there are no studies in Turkish context that specifically focus on distance education environments and success.

\subsection{Student satisfaction in Distance Education}

There are several elements that influence student satisfaction in online environments (Bolliger \& Wasilik, 2009). Bollinger and Martindale (2004) discovered that the factors that influence learner satisfaction were the instructor, technology, and interactivity. Other factors were communication with all other course constituents, course management issues, and course websites or course management systems used.

Higher education institutions consider student satisfaction as one of the major elements in determining the quality of online programs in today's markets (Yukselturk \& Yildirim, 2008). Student satisfaction in online programs has been studied in relation to a number of factors such as persistence (Allen \& Seaman, 2008), retention (Debourgh, 1999; Koseke, \& Koseke, 1991), course quality (Moore \& Kearsley, 1996), and student success (Keller, 1983; Pike, 1993). Findings indicate that high satisfaction leads to higher levels of retention, higher persistence in learning, and higher motivation (Keller, 1983; Koseke, \& Koseke, 1991). There is no doubt that research on satisfaction help course designers, educators and administrators to work on 
areas that need improvement (Reinhart \& Schneider, 2001).

Şahin (2007) carried out a similar study to the present one in Turkish context and found that personal relevance, instructor help, active learning, and authentic learning were the key factors that support students' learning and increase their satisfaction. Among these variable in his study, personal relevance was found to be the strongest predictor of student satisfaction. Accordingly, the author suggests that students who are able to link course content with their personal experiences tend to be more satisfied in distance education. Therefore, it is possible to claim that online learning environments should be learner-centered and involve students' out-of-school knowledge and skills. In another study in Turkish context, Yükseltürk and Y1ldirım (2008) investigated interaction, online support, course structure and flexibility as the contributing factors to students' satisfaction in an online program. They found a significant correlation between student satisfaction and interaction.

Recently, a number of research studies have found that interaction has a positive influence on student satisfaction in distance education (Bray et al., 2008; Burnett, 2001; Northrup, Lee \& Burgess, 2002; Thurmond \& Wambach, 2004). In these studies, interaction is conceptualized as learner-learner interaction, learner-instructor interaction, and learner-content interaction. Of these studies, it can be seen that learner-learner interaction and learner-instructor interaction are stronger predictors of student satisfaction rather than learner-content interaction (Bolliger \& Martindale, 2004; Jung, Choi, Lim \& Leem, 2002; Rodriguez, 2006; Thurmond, 2003). Battalio's (2007) study suggested that learner-instructor interaction was the most required interaction. In this study, the interaction variable is conceptualized as student interaction and collaboration. Quite recently, Kuo, Walker, Belland, and Schroder (2013) worked on the degree to which interaction and other predictors contribute to student satisfaction in online learning settings. They found that learner-instructor interaction, learner-content interaction, and Internet self-efficacy were good predictors of student satisfaction while interactions among students and self-regulated learning did not contribute to student satisfaction. Learner-content interaction explained the largest unique variance in student satisfaction.

The present study aims at answering the following questions:

1. What are the perceptions of ELL distance education students in terms of the following variables:
a. instructor support
b. student interaction and collaboration,
c. personal relevance,
d. authentic learning,
e. active learning,
f. student autonomy, and
g. satisfaction

2. What are the predictors of success in the specified online program?

3. What are the predictors of satisfaction in the specified online education program? 


\section{Macrothink}

4. What is the correlation between satisfaction and academic achievement?

5. Do participants differ in their views on:
a. instructor support
b. student interaction and collaboration,
c. personal relevance,
d. authentic learning,
e. active learning,
f. student autonomy, and
g. satisfaction

in relation to factors like age, gender, and class level?

\section{Method}

\subsection{Research Design}

This study is based on survey method. Correlation analyses were carried out in order to determine the relation between student success and achievement and the independent variables of the study.

\subsection{Procedure and Participants}

Data was collected during the fall term of 2014 academic year. Since the participants of the study are distance education students, data collection process was realized during the exam period. The participants were given written instructions that explained the purpose of the study and the procedure they were to follow. Descriptive and correlation tests were conducted to analyze the data.

The study included 84 students who attend the English Language and Literature Department at Karabuk University. The number of female students $(\mathrm{N}=50)$ was greater than the number of male students $(\mathrm{N}=34)$. In terms of age groups, there is almost the same number of students in the three age groups $(21-25,25-30,31-35)$ while there are only two students who are over 36. The number of third level students $(\mathrm{N}=54)$ is greater than that of second level students $(\mathrm{N}=30)$. Table 1 presents the demographic characteristics of the students. 
Table 1. Demographic characteristics of the participants

\begin{tabular}{lll}
\hline & N & P \\
\hline Gender & & \\
\hline Female & 50 & 59.5 \\
Male & 34 & 40.5 \\
\hline Age & & \\
\hline $21-25$ & 27 & 32.1 \\
$25-30$ & 28 & 33.3 \\
$31-35$ & 27 & 32.1 \\
$36-$ over & 2 & 2.4 \\
\hline Class level & & \\
\hline $2^{\text {nd }}$ class & 30 & 35.7 \\
$3^{\text {rd }}$ class & 54 & 64.3 \\
\hline
\end{tabular}

\subsection{Instrumentation}

Data for the present study was collected through Education Learning Environment Survey (DELES). This instrument was developed and validated by Walker \& Fraser (2005). The DELES scales were made up of a total of 42 items. It considers post-secondary student and instructor perceptions of their learning environment in six psychosocial scales: 1) instructor support, 2) student interaction and collaboration, 3) personal relevance, 4) authentic learning, 5) active learning, and 6) student autonomy. The DELES also includes a student satisfaction scale focused on enjoyment of distance education, and thus allows researchers to investigate relations between student satisfaction and the psychosocial learning environment.

\subsection{Data Analysis}

The SPSS 15 package was used for data analysis. Data set was examined carefully, and defective and incorrect data were removed prior to analyses conducted in accordance with the research purposes. First of all, descriptive statistics were run in order to see the level of the participants in terms of all the variables of the study: a. instructor support, (b) student interaction and collaboration, (c) personal relevance, (d) authentic learning, (e) active learning, (f) student autonomy, and (g) satisfaction. In order to answer the second question of the study, a correlation analysis was carried out in order to see the coherence among the variables of the study. Then, a multiple regression analysis was conducted to determine the predictors of success in distance education. Similarly, a correlation and multiple regression analyses were carried out in order to answer the third research question. As to the fourth question, a correlation analysis was conducted. Finally, in order to answer the last question, an ANOVA test was conducted in order to see whether participants differ in their views of the variables of the study in relation to age group, and two t-tests were carried out in order to see whether the participants differ in the variables of the study in relation to gender and grade level. 


\section{Findings}

4.1 Research question 1: What are the perceptions of ELL distance education students in terms of the following variables: (a) instructor support, (b) student interaction and collaboration, (c) personal relevance, (d) authentic learning, (e) active learning, (f) student autonomy, and (g) satisfaction?

Table 2. Descriptive statistics regarding the variables of the study

\begin{tabular}{lccccc}
\hline Variable & $\overline{\boldsymbol{X}}$ & $\boldsymbol{S D}$ & Min & Max & Range \\
\hline Instructor support & 14.33 & 3.53 & 4 & 20 & 16 \\
Student interaction and collaboration & 14.12 & 3.74 & 4 & 20 & 16 \\
Personal relevance & 15.24 & 3.32 & 5 & 20 & 15 \\
Authentic learning & 18.40 & 3.82 & 5 & 25 & 19 \\
Active learning & 11.90 & 2.23 & 3 & 15 & 12 \\
Learner autonomy & 19.70 & 3.33 & 7 & 25 & 18 \\
Satisfaction & 17.90 & 4.08 & 5 & 25 & 20 \\
\hline
\end{tabular}

Table 2 presents the descriptive statistics about the variables of the study. As we can understand from the table, the mean score of the participants for the instructor support variable is 14.33 . Considering that the total point for this variable is 20 , we can say that students have significantly high level of instructor support. The mean score for the second variable is 14.12, which indicates that the participants have positive attitudes in terms of student interaction and collaboration. As for personal relevance, the mean score is 15.24. This shows that the participants believe that what they are learning in the program can be related to their personal expectations. The next variable is authentic learning, and the mean score for this variable is 18.40 . We can understand that the participants believe that the course material they deal with is authentic enough. For the next variable, active learning, the mean score is 11.90, indicating that the participants believe that they have an active learning process. As for learner autonomy, the mean score is 19.70 . We can understand that the participants have a high level of autonomy beliefs. Finally, as for satisfaction we can see that the mean score is 17.90. Considering that the top score is 25 , it is possible to speculate that the participants are highly satisfied with their learning program.

We can understand from Table 2 that the participants have the highest mean scores from the following variables: student satisfaction, learner autonomy, and authentic learning. The close relation between learner autonomy and satisfaction has been reported by some researchers (Luskin \& Hirsen, 2010). The connection between satisfaction and learner autnomy was also voiced by Ferrer-Cascales et al. (2011).

4.2 Research question 2. What are the predictors of success in the distance education program?

In order to see the correlation among the variables of the study, a correlation analysis was carried out. The results are given in Table 3. The correlation co-efficients range between .129 
and .668, which indicates that there are no problems in terms of multi-collinearity. In addition, the positive relation between independent variables and the dependent variables was tested. The results of the analysis indicate that the correlation values range from .093 to .322 . The results of the multiple regression analysis that was carried out in order to investigate the relation between the independent variables of the study, a) instructor support, (b) student interaction and collaboration, (c) personal relevance, (d) authentic learning, and (e) active learning, and the dependent variable, academic success are given in Table 4. We can understand from these results that the academic success is influenced by active learning, personal relevance, and satisfaction. However, instructor support, student interaction and collaboration, authentic learning and learner autonomy do not influence academic success.

Table 3. Correlation co-efficients for the variables of the study

\begin{tabular}{lcccccccc}
\hline Variables & Aca.Ach. & Rel. & Inssup & Sat & Act & Authent & Auto & Int \\
\hline Academic achievement & & $.322^{*}$ & $.238^{*}$ & $.273^{*}$ & $.240^{*}$ & .093 & $.192^{*}$ & $.208^{*}$ \\
Relevance & $.322^{*}$ & & $.508^{*}$ & $.600^{*}$ & $.347^{*}$ & $.520^{*}$ & $.353^{*}$ & $.436^{*}$ \\
Insturaction support & $.238^{*}$ & $.508^{*}$ & & $.654^{*}$ & $.278^{*}$ & $.484^{*}$ & $.290^{*}$ & $.541^{*}$ \\
Satisfaction & $.273^{*}$ & $.600^{*}$ & $.654^{*}$ & & $.460^{*}$ & $.662^{*}$ & $.458^{*}$ & $.530^{*}$ \\
Active learning & $.240^{*}$ & $.347^{*}$ & $.278^{*}$ & $.460^{*}$ & & $.508^{*}$ & $.698^{*}$ & .092 \\
Authententic learning & .093 & $.520^{*}$ & $.484^{*}$ & $.662^{*}$ & $.508^{*}$ & & $.484^{*}$ & $.473^{*}$ \\
Autonomy & $.192^{*}$ & $.353^{*}$ & $.290^{*}$ & $.458^{*}$ & $.698^{*}$ & $.484^{*}$ & & .129 \\
Int & $.208^{*}$ & $.436^{*}$ & $.541^{*}$ & $.530^{*}$ & .092 & $.473^{*}$ & .129 & \\
\hline
\end{tabular}

Aca.Ach=academic achievement

Rel $=$ Personal relevance

Inssup Sup: Instructor support

Act $=$ active learning

Authent: authentic learning

Auth: autonomy

Int $=$ Student interaction and collaboration

The direction of the relation between the dependent and independent variables was investigated through distribution diagram and the results are given in Figure 1. 


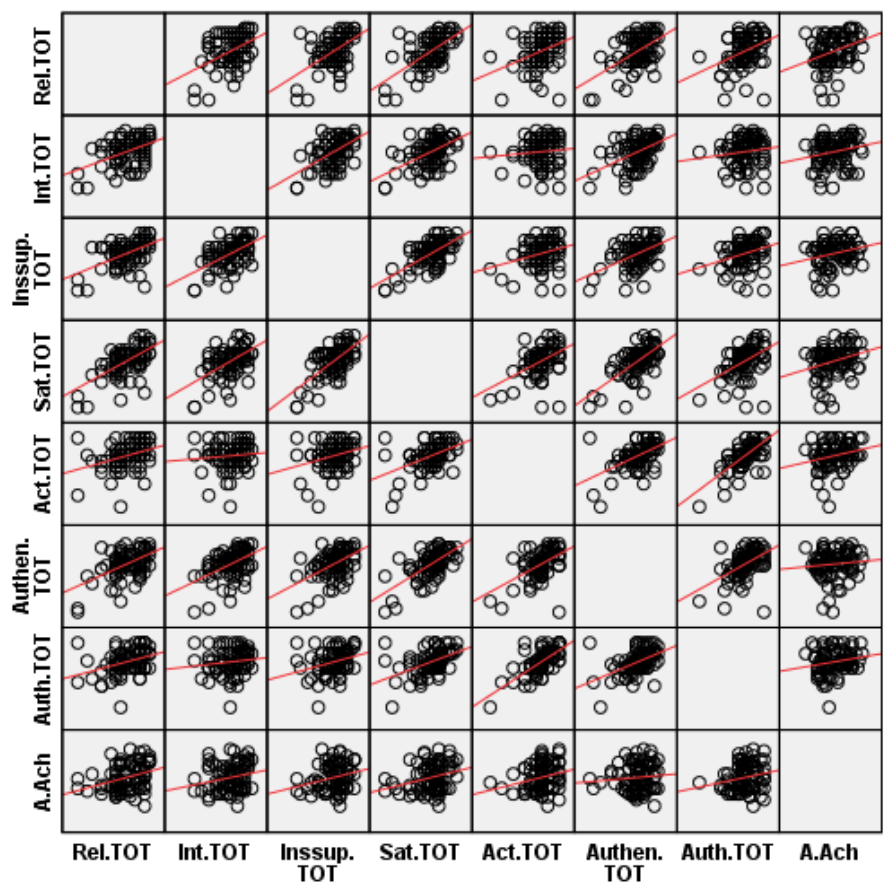

Figure 1. The distribution of dependent and independent variables

When Figure 1 is examined, it can be argued that the relation between academic success and the independent variables is positive. After these analyses, multiple regression analysis was carried out. The results are presented in Table 3.

Table 4. Results of multiple regression analysis for the predictors of academic success

\begin{tabular}{lccccccc}
\hline Variables & B & $\begin{array}{c}\text { Standard } \\
\text { deviation B }\end{array}$ & B & t & p & double & Partial \\
Constant & 1.394 & .342 & & 4.081 & .000 & & r \\
Personal relevance & .035 & .019 & .250 & 1.837 & .070 & .322 & .206 \\
Instructor support & .006 & .019 & .045 & .311 & .757 & .238 & .036 \\
Satisfaction & .014 & .020 & .126 & .725 & .471 & .273 & .083 \\
Active learning & .047 & .032 & .227 & 1.475 & .144 & .240 & .167 \\
Authentic learning & -.040 & .019 & -.334 & -2.174 & .033 & .093 & -.242 \\
Autonomy & .002 & .021 & .017 & .115 & .908 & .192 & .013 \\
Student interaction and & .018 & .017 & .143 & 1.043 & .300 & .208 & .119 \\
collaboration & & & & & & & \\
\hline$R=.427, R^{2}=.182, F(7,76)=2.416, p=.027$ & & & & & \\
\hline
\end{tabular}

When we examine Table 4, it can be understood that the multiple regression equation is significant. $\left(\mathrm{F}_{(7,76)}=2.416, p<.05\right)$. All the independent variables account for $18.2 \%$ of the dependent variable, academic success. When we examine $\beta$ regression values, the relative order of the independent variables is as follows: authentic learning, personal relevance, active learning, student interaction and collaboration, satisfaction, instructor support, and autonomy. However, the only variable that significantly influences success was found to be authentic 


\section{Mll Macrothink}

learning. The regression equation is as follows: Academic success $=1.394+(.035 *$ personal relevance $)+(.006 *$ Instructor support $)+(.014 *$ satisfaction $)+(.047 *$ Active learning $)+(-.040 *$ Authentic learning $)+(.002 *$ autonomy $)+(.018 *$ student interaction and collaboration).

4.3 Research question 3: What are the predictors of satisfaction in the distance education program?

A multiple regression test was carried out in order to investigate the influence of (a) instructor support, (b) student interaction and collaboration, (c) personal relevance, (d) authentic learning, (e) active learning, and (f) student autonomy on student satisfaction. The results are given in Table 4 . When we analyze the correlation among the variables, it can be seen that the correlation coefficients range between .093 and .698. These correlation co-efficients indicate that there are no problems as regards multi-collinearity. In addition, prior to the analysis, the significance of the correlation between the dependent and independent variables was tested. The results showed that the correlation values range between .458 and .654 (see table 4), which indicated that the correlation between the dependent and independent variables was significant. The linearity of the relationship between the dependent and independent variables is given in Figure 2.

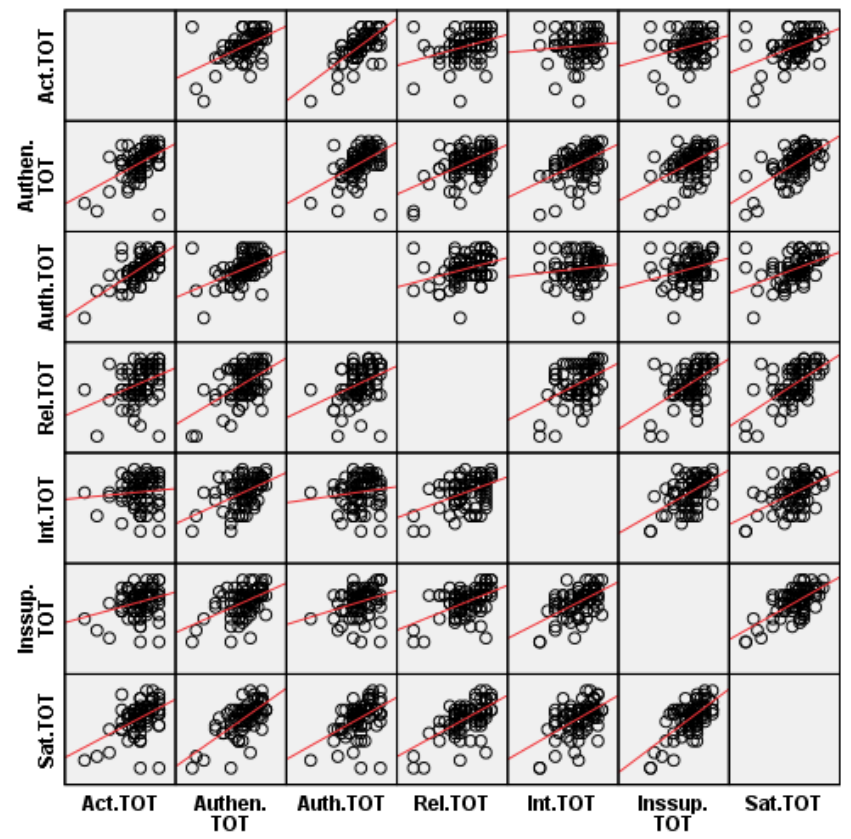

Figure 2. The distribution of dependent and independent variables

Having, thus, investigated the pre-requisites of correlation analysis and found that they all conform to these pre-requisites, the next step was to carry out the multiple regression analysis. The results are given in Table 5. 
Table 5. Results of multiple regression for predictors of satisfaction

\begin{tabular}{lccccccc}
\hline Variables & B & $\begin{array}{c}\text { Standard } \\
\text { Error B }\end{array}$ & $\beta$ & $\mathrm{t}$ & $\mathrm{p}$ & $\begin{array}{c}\text { double } \\
\mathrm{r}\end{array}$ & partial r \\
\hline Constant & -2.273 & 1.962 & & -1.159 & .250 & & \\
Personal Relevance & .223 & .107 & .182 & 2.095 & .039 & .600 & .232 \\
Active Learning & .198 & .184 & .108 & 1.076 & .285 & .460 & .122 \\
Instructor Support & .351 & .103 & .304 & 3.422 & .001 & .654 & .363 \\
Interaction and Collaboration & .158 & .096 & .145 & 1.651 & .103 & .530 & .185 \\
Authentic Learning & .271 & .103 & .254 & 2.632 & .010 & .662 & .287 \\
Autonomy & .109 & .120 & .089 & .913 & .364 & .458 & .104 \\
\hline$R=.802, R^{2}=.644, F(6,77)=23.175, p=.000$ & & & & & \\
\hline
\end{tabular}

Table 5 indicates that the relation between the six independent variables and the dependent variable is significant $\left(\mathrm{F}_{(6,77)}=23.175, p<.05\right)$. The results suggest that all the six independent variables account for $64,4 \%$ of the total variance in terms of student satisfaction. When the standardized regression co-efficient is examined, the relative order of important is as follows: (1) instructor support, (2) authentic learning, (3) personal relevance, (4) student interaction and collaboration, (5) active learning, and (6) autonomy. However, among the independent variables instructor support (p. $001<.05$ ), authentic learning (p. $010<.05$ ), and personal relevance $(\mathrm{p} .039<.05)$ were found to be significant predictors of student satisfaction. The regression equation is as follows: Satisfaction $=(-2.273)+(0.223 *$ Personal relevance $)+(0.198 *$ Active learning $)+(0.351 *$ Instructor support $)+(0.158 *$ Student interaction and collaboration $)+(0.271 *$ Authentic learning $)+(0.109 *$ Autonomy $)$.

4.4 Research question 4: What is the correlation between satisfaction and academic achievement?

Within the scope of the study, the relationship between satisfaction and academic success was investigated. The distribution diagram is given in Figure 3. 


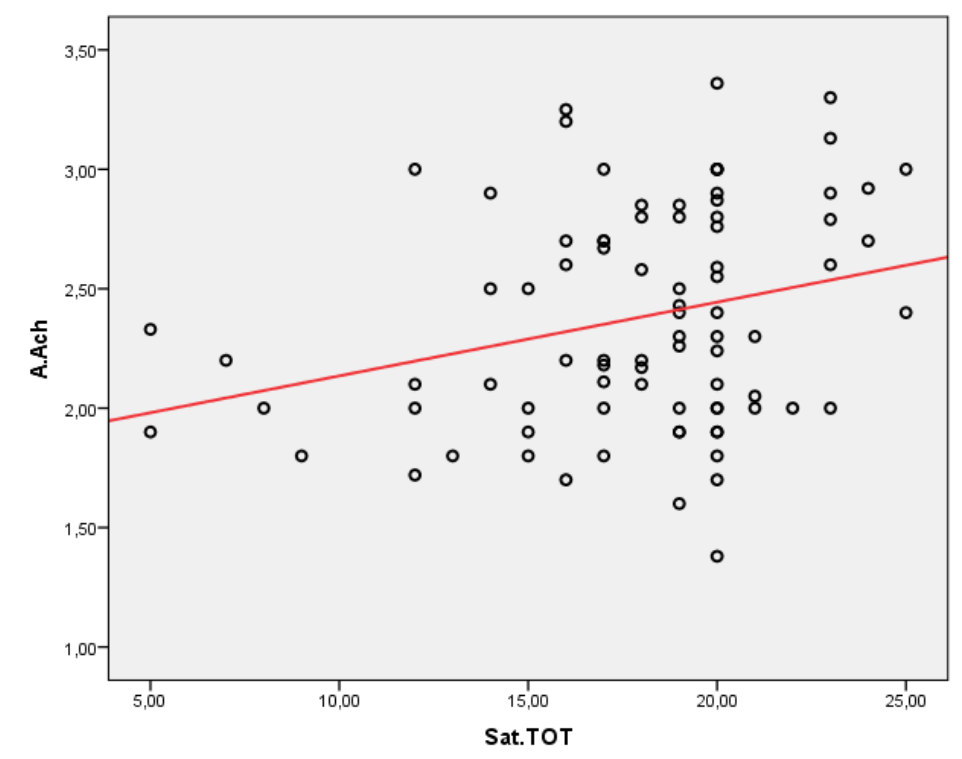

Figure 3. The distribution diagram of academic success and satisfaction

When we examine Figure 3, we can see that there is a rather weak positive relation between satisfaction and academic success. In order to test whether the relationship is statistically significant, Pearson product-moment correlation was carried out and the co-efficient was .273, and this shows that the relationship is significant $(r=0.273, p<.05)$. That is to say, there is a significant relationship between academic success and satisfaction. The determination co-efficient indicates that satisfaction account for $7.45 \%$ of academic success for distance education students.

4.5 Research question 5: Do participants differ in their views on (a) instructor support, (b) student interaction and collaboration, (c) personal relevance, (d) authentic learning, (e) active learning, (f). student autonomy, and (g) satisfaction in relation to factors like age, gender, and class level?

In order to understand whether gender accounts as a determiner in regard to the participants views on the variables of the study, a t-test was carried out. The results are given in Table 6 . As we can understand from the results, there are no statistically significant differences between male and female participants in terms of their views on (a) instructor support $(p>.05)$, (b) student interaction and collaboration $(p>.05)$, (c) personal relevance $(p>.05)$, (d) authentic learning $(p>.05)$, (e) active learning $(p>.05)$, (f). student autonomy $(p>.05)$, and $(\mathrm{g})$ satisfaction $(\mathrm{p}>.05)$. 
Table 6. T-test result for gender

\begin{tabular}{llllll}
\hline Variables & status & $\mathrm{N}$ & $\mathrm{M}$ & $\mathrm{t}$ & Sig. \\
\hline Instructor support & male & 34 & 29,2400 &,- 178 &, 859 \\
& female & 50 & 29,4706 & & \\
Student interaction and collaboration & male & 34 & 18,6000 &, 454 &, 651 \\
& female & 50 & 18,1765 & & \\
Personal relevance & male & 34 & 26,3400 &,- 313 &, 755 \\
& female & 50 & 26,6765 & & \\
Authentic learning & male & 34 & 18,5200 &, 333 &, 740 \\
& female & 50 & 18,2353 & & \\
Active learning & male & 34 & 11,9000 &, 345 &, 747 \\
& female & 50 & 11,9118 & & \\
Learner autonomy & male & 34 & 19,8000 &, 204 &, 981 \\
p $<.05$ & female & 50 & 19,5588 & & \\
Satisfaction & male & 34 & 17,9800 &,- 024 &, 839 \\
& female & 50 & 17,7941 & & \\
\hline
\end{tabular}

As a next step, another t-test was conducted in order to see whether there are statistically significant differences between $2^{\text {nd }}$ and $3^{\text {rd }}$ grade students in terms of their views on the variables of the study. The results are presented in Table 7 .

Table 7. T-test result for grade level

\begin{tabular}{llllll}
\hline Variables & status & $\mathrm{N}$ & $\mathrm{M}$ & $\mathrm{t}$ & $\mathrm{S}$ Sig. \\
\hline Instructor support & $2^{\text {nd }}$ grade & 30 & 27,9333 & $-1,667$ & .09 \\
& $3^{\text {rd }}$ grade & 54 & 30,1111 & & \\
Student interaction and collaboration & $2^{\text {nd }}$ grade & 30 & 18,5000 &, 116 & .90 \\
& $3^{\text {rd }}$ grade & 54 & 18,3889 & & \\
Personal relevance & $2^{\text {nd }}$ grade & 30 & 25,3667 & $-1,591$ & .12 \\
& $3^{\text {rd }}$ grade & 54 & 27,0926 & & \\
Authentic learning & $2^{\text {nd }}$ grade & 30 & 17,3000 & $-2,009$ & $\mathbf{. 0 4}$ \\
\hline
\end{tabular}




\begin{tabular}{lllllll}
\hline & $3^{\text {rd }}$ grade & 54 & 19,0185 & & \\
Active learning & $2^{\text {nd }}$ grade & 30 & 19,9667 &, 540 & .59 \\
& $3^{\text {rd }}$ grade & 54 & 19,5556 & & \\
Learner autonomy & $2^{\text {nd }}$ grade & 30 & 11,6667 &,- 729 & .46 \\
& $3^{\text {rd }}$ grade & 54 & 12,0370 & & \\
Satisfaction & $2^{\text {nd }}$ grade & 30 & 17,0667 & $-1,411$ & .16 \\
& $3^{\text {rd }}$ grade & 54 & 18,3704 & & \\
\hline & & & & &
\end{tabular}

we can understand from Table 7 that there are no statistically significant differences between $2^{\text {nd }}$ and $3^{\text {rd }}$ level students in terms of (a) instructor support $(\mathrm{p}>.05)$, (b) student interaction and collaboration $(p>.05)$, (c) personal relevance $(p>.05)$, (d) active learning $(p>.05)$, (e) student autonomy $(\mathrm{p}>.05)$, and $(\mathrm{f})$ satisfaction $(\mathrm{p}>.05)$. However, statistically significant difference was observed between $2^{\text {nd }}$ grade and $3^{\text {rd }}$ grade students in terms of authentic learning $(\mathrm{p}<.05)$. The results indicate that the mean score for $2^{\text {nd }}$ grade students is 17.3000 , while the mean score for the $3^{\text {rd }}$ grade students is 19.0185 . It can be understood that $3^{\text {rd }}$ grade students find their learning materials more authentic.

Finally, an ANOVA was conducted in order to see whether participants from different age groups differ in relation to the variables of the study. The age groups in the study range from 21-25, 26-30, to 31-35. The results are presented in Table 8. The results show that there are no statistically significant differences among the age groups in relation to (a)student interaction and collaboration $(\mathrm{p}>.05)$, (b) personal relevance $(\mathrm{p}>.05)$, (c) active learning $(\mathrm{p}>.05)$, (d) student autonomy $(\mathrm{p}>.05)$, and $(\mathrm{e})$ satisfaction $(\mathrm{p}>.05)$. A statistically significant difference was observed in relation to instructor support $(\mathrm{p}<.05)$.

Table 8. ANOVA results for age groups

\begin{tabular}{|c|c|c|c|c|c|}
\hline Variables & status & $\mathrm{N}$ & M & $\mathrm{f}$ & Sig. \\
\hline \multirow{3}{*}{ Instructor support } & $21-25$ & 27 & 27,0000 & 3,580 & \multirow{3}{*}{,032 } \\
\hline & $26-30$ & 28 & 30,8929 & & \\
\hline & $31-35$ & 27 & 30,1111 & & \\
\hline \multirow{3}{*}{ Student interaction and collaboration } & $21-25$ & 27 & 18,5926 & ,276 & \multirow{3}{*}{,759 } \\
\hline & $26-30$ & 28 & 18,7143 & & \\
\hline & $31-35$ & 27 & 17,9259 & & \\
\hline \multirow{2}{*}{ Personal relevance } & $21-25$ & 27 & 25,5926 & 1,292 & \multirow{3}{*}{,280 } \\
\hline & $26-30$ & 28 & 27,5714 & & \\
\hline \multirow{4}{*}{ Authentic learning } & $31-35$ & 27 & 26,7037 & & \\
\hline & $21-25$ & 27 & 17,8889 & 2,331 & \multirow{3}{*}{104} \\
\hline & $26-30$ & 28 & 19,7143 & & \\
\hline & & & 17,8889 & & \\
\hline
\end{tabular}




\begin{tabular}{lllllll}
\hline & $31-35$ & 27 & & & \\
Active learning & $21-25$ & 27 & 19,8519 &, 018 &, 982 \\
& $26-30$ & 28 & 19,8929 & & \\
& $31-35$ & 27 & 19,7407 & & \\
Learner autonomy & $21-25$ & 27 & 11,5926 & 1,696 &, 190 \\
& $26-30$ & 28 & 12,5357 & & \\
Satisfaction & $31-35$ & 27 & 11,7778 & & \\
& $21-25$ & 27 & 16,8889 & 1,769 & \\
& $26-30$ & 28 & 18,4286 & & \\
& $31-35$ & 27 & 18,7037 & & \\
\hline
\end{tabular}

\section{Discussion and Conclusion}

One of the primary goals of the present study was to investigate the predictors of academic success in the distance education program. Research indicates that motivation, locus of control, and self-regulation are among the primary predictors of success in distance education program while age, gender, or personal characteristics were not found to correlate with academic success in distance education (Yükseltürk \& Bulut, 2008, Lim, 2001; Wang \& Newlin, 2002). The present study investigated academic success in relation to factors such as (1) instructor support, (2) authentic learning, (3) personal relevance, (4) student interaction and collaboration, (5) active learning, and (6) autonomy. The multiple regression analysis revealed that the only variable that influenced academic success was authentic learning in the present study.

The literature indicates the three factors as the most important predictors of satisfaction, which are students, the instructor and the institution (Bollinger \& Wassilik, 2009). The findings of the present study also confirmed these findings. In the present study, the factors that predict student satisfaction were instructor support, authentic learning, and personal relevance. In the Turkish context, Şahin (2007) carried out a study on the same variables as those of the present study and concluded that instructor support, personal relevance, and authentic learning. These findings are the same as the findings of the present study. More specifically, this study found a relation between satisfaction and learner autonomy, which is in line with the findings of Ferrer-Cascales et al. (2011).

Literature indicates that there is a positive correlation between learner satisfaction and student performance. That is to say, the level of faculty satisfaction is higher in courses where student performance is better (Fredericksen et al., 2000; Hartman et al., 2000). Although the relationship was rather weak, the present study also found a positive correlation between satisfaction and academic achievement.

As a next step, the study investigated whether the participants differ in terms of their views on the variables of the study in relation to age, gender, and grade level. Tests of variance such 
as t-test and ANOVA were conducted and the results indicated that there are no statistically significant differences between male and female students in terms of the variables of the study. As for the grade level, statistically significant difference was observed between $2^{\text {nd }}$ grade and $3^{\text {rd }}$ grade students in authentic learning. Third grade students favored authentic learning more than $2^{\text {nd }}$ grade students. Finally, a statistically significant difference was also observed between age groups in terms of Instructor support.

The present study attempted to investigate the predictors of success and satisfaction in an online distance education program in Turkish context. The independent variables of the study were (1) instructor support, (2) authentic learning, (3) personal relevance, (4) student interaction and collaboration, (5) active learning, and (6) autonomy. As for the first research question, the results indicated that the students were found to have strong results in terms of student satisfaction, learner autonomy, and authentic learning. The second research question inquired the predictors of success among the given independent variables and the results indicated that authentic learning was the only strong predictor of success. As for the third, research question, the main predictors of satisfaction were found to be instructor support, authentic learning, and personal relevance. Regarding the relation between learner satisfaction and success, the study found a moderate level of correlation between the two variables. Finally, the study investigated whether the participants differed significantly in terms of age, gender, and grade level on their perceptions of the variables of the study. The results indicated that $3^{\text {rd }}$ level students ranked their learning higher in terms of authentic learning.

Pedagogically, the results of the study found support for the important of authentic learning, learner autonomy, personal relevance, and instructor support. These elements are the important elements of constructivist learning. We understand that instruction must cater for the basic tenets of constructivism. The present study has accentuated the importance of authentic learning in both satisfaction and academic success. Therefore, course contents should be "of immediate real-life value" (Yükseltürk and Bulut, 2007) for the students and should contain a variety of materials to enrich the content.

The present study was carried out in one particular context. In future studies, different contexts can be focused in order to provide more generalizable results. Since the present study was based on DELES survey, some other factors like motivation or self-efficacy were not included among the variables of the study. Future studies can incorporate motivation variable.

\section{References}

Allen, I. E., \& Seaman, J. (2008). Staying the course: Online education in the United States, Sloan Consortium report.

Allen, M., Bourhis, J., Burrell, N., \& Mabry, E. (2002). Comparing student satisfaction with distance education to traditional classrooms in higher education: A meta-analysis. The American Journal of Distance Education, 16(2), 83-97. 
http://dx.doi.org/10.1207/S15389286AJDE1602_3

Battalio, J. (2007). Interaction online: A reevaluation. Quarterly Review of Distance Education, 8(4), 339-352.

Biner, P. M., Summers, M., Dean, R. S., Bink, M. L., Anderson, J. L., \& Gelder, B. C. (1996). Student satisfaction with interactive telecourses as a function of demographic variables and prior telecourse experience. Distance Education, 17(1), 33-43. http://dx.doi.org/10.1080/0158791960170104

Bolliger, D. U., \& Martindale, T. (2004). Key factors for determining student satisfaction in online courses. International Journal on E-Learning, 3(1), 61-67.

Bolliger, D.U.,\& Wasilik, O. (2009).Factors influencing faculty satisfaction with online teaching and learning in higher education. Distance Education, 30(1), 103-116. http://dx.doi.org/10.1080/01587910902845949

Bray, E., Aoki, K., \& Dlugosh, L. (2008). Predictors of learning satisfaction in Japanese online distance learners. International Review of Research in Open \& Distance Learning, $9(3), 1-24$.

Burnett, K. (2001). Interaction and student retention, success and satisfaction in web-based learning. Retrieved from ERIC database. (ED459798).

Debourgh, G. (1999). Technology is the tool, teaching is the task: Student satisfaction in distance learning. Paper presented at the Society for Information and Technology \& Teacher Education International Conference, San Antonio, TX.

Dille, B., \& Mezack, M. (1991). Identifying predictors of high risk among community college students. American Journal of Distance Education, 5(1), 24-35. http://dx.doi.org/10.1080/08923649109526729

Ferrer-Cascales, R., Walker, S.L., Reig-Ferrer, A., Fernández-Pascual, M.D., \& Albaladejo-Blázquez, N. (2011). Evaluation of hybrid and distance education learning environments in Spain. Australasian Journal of Educational Technology, 27(7), 1100-1110.

Fredericksen, E., Pickett, A., Shea, P., Pelz, W., \& Swan, K. (2000). Factors influencing faculty satisfaction with asynchronous teaching and learning in the SUNY learning network. Journal of Asynchronous Learning Networks, 4(3), 245-278.

Hartman, J., Dziuban, C., \& Moskal, P. (2000). Faculty satisfaction in ALNs: A dependent or independent variable? Journal of Asynchronous Learning Networks, 4(3), 155-177.

Jung, I., Choi, S., Lim, C., \& Leem, J. (2002). Effects of different types of interaction on learning achievement, satisfaction and participation in web-based instruction. Innovations in Education \& Teaching International, 39(2), 153-162. http://dx.doi.org/10.1080/14703290252934603

Kaminski, K., Switzer, J., \& Gloeckner, G. (2009). Workforce readiness: A study of university 
students' fluency with information technology. Computers \& Education, 53(2), 228-233. http://dx.doi.org/10.1016/j.compedu.2009.01.017

Keller, J. M. (1983). Motivational design of instruction. In C. Reigeluth (Ed.), Instructional design theories and models: An overview of their current status (pp. 386-434). Hillsdale, NJ: Erlbaum.

Keller, J. M. (1999). Motivation in cyber learning environments. International Journal of Educational Technology, 1(1), 7-30.

Koseke, G. F., \& Koseke, R. D. (1991). Student burnout as a mediator of the stress-outcome relationship. Research in Higher Education, 32(4), 415-431. http://dx.doi.org/10.1007/BF00992184

Kuo, Y., Walker, A.E., Belland, B.R., \& Schroder, K.E.E. (2013). A Predictive Study of Student Satisfaction in Online Education Programs. The International Review of Research in Open and Distance Learning, 14(1), 16-39.

Lim, C. K. (2001). Computer self-efficacy, academic self-concept, and other predictors of satisfaction and future participation of adult distance learners. The American Journal of Distance Education, 15(2), 41-51. http://dx.doi.org/10.1080/08923640109527083

Loomis, K. D. (2000). Learning styles and asynchronous learning: Comparing the LASSI model to class performance. Journal of Asynchronous Learning Networks, 4(1), 23-32.

Luskin, B., \& Hirsen, J. (2010). Media psychology controls the mouse that roars. In K. E. Rudestam \& J. Schoenholtz-Read (Eds.), Handbook of Online Learning. Thousand Oaks, CA: SAGE Publications, Inc.

Moore, M. G., \& Kearsley, G. (1996). Distance education: A systems view. New York, NY: Wadsworth.

Northrup, P., Lee, R., \& Burgess, V. (2002). Learner perceptions of online interaction. Paper presented at ED-MEDIA 2002 World Conference on Educational Multimedia, Hypermedia \& Telecommunications, Denver, CO.

Parker, A. (1999). A study of variables that predict dropout from distance education. International Journal of Educational Technology, 1(2), 1-10.

Phipps, R., \& Merisotis, J. (1999). What's the Difference? A review of Contemporary Research on the Effectiveness of Distance Education in Higher Education. Institute for Higher Education Policy.

Pike, G. R. (1993). The relationship between perceived learning and satisfaction with college: An alternative view. Research in Higher Education, 34(1), 23-40. http://dx.doi.org/10.1007/BF00991861

Rodriguez R. F. M. (2006). Learner characteristic, interaction and support service variables as predictors of satisfaction in Web-based distance education. Dissertation Abstracts International, 67(7), (UMI No. 3224964). 
Şahin, İ. (2007). Predicting student satisfaction in distance education and learning environments. Turkish Online Journal of Distance Education-TOJDE, 8.

Sankaran, S. R., \& Bui, T. (2001). Impact of learning strategies and motivation on performance: A study in Web-based instruction. Journal of Instructional Psychology, 28(3), 191-198.

Shih, C., \& Gamon, J. (2001). Web-based learning: Relationships among student motivation, attitude, learning styles, and achievement. Journal of Agricultural Education, 42(4), 12-20. http://dx.doi.org/10.5032/jae.2001.04012

Şimsek, A., \& Balaban, J. (2010). Learning strategies of successful and unsuccessful university students. Contemporary Educational Technology, 1(1), 36-45.

Song, S. H. (2000). Research issues of motivation in Web-based instruction. Quarterly Review of Distance Education, 1(3), 225-229.

Stone, T. E. (1992). A new look at the role of locus of control in completion rates in distance education. Research in Distance Education, 4(2), 6-9.

Thurmond, V. A., \& Wambach, K. (2004). Understanding interactions in distance education: A review of the literature. International Journal of Instructional Technology and Distance Learning, 1(1), 9-26.

Tok, H., Özgan, H., \& Dös, B. (2010). Assessing metacognitive awareness and learning strategies as positive predictors for success in a distance learning class. Mustafa Kemal University Journal of Social Sciences Institute, 7(14), 123 - 134.

Walker, S.L., \& Fraser, B.J. (2005). Development and validation of an instrument for assessing distance education learning environments in higher education: the distance education learning environments survey (DELES). Learning Environments Research, 8, 289-308. http://dx.doi.org/10.1007/s10984-005-1568-3

Walker. S. L. (2003). Distance education learning environments research: A short history of a new direction in psychosocial learning environments. Paper presented at the Eighth Annual Teaching in the Community Colleges Online Conference. Honolulu. bHI.

Wang, A.Y., \& Newlin, M. H. (2002). Predictors of web-student performance: The role of self-efficacy and reasons for taking an on-line class. Computers in Human Behavior, 18(2), 151-163. http://dx.doi.org/10.1016/S0747-5632, (01)00042-5

Wang, X.C., Hinn, D.M., \& Kanfer, A.G. (2001). Potential of computer-supported collaborative learning for learners with different learning styles. Journal of Research on Technology in Education, 34(1), 75-85. http://dx.doi.org/10.1080/15391523.2001.10782335

Yükseltürk, E., \& Bulut, S. (2007). Predictors for Student Success in an Online Course. Educational Technology \& Society, 10(2), 71-83.

Yükseltürk, E., \& Yildirim, Z. (2008). Investigation of interaction, online support, course 
structure and flexibility as the contributing factors to students' satisfaction in an online certificate program. Educational Technology \& Society, 11(4), 51-65.

Zimmerman, B. J. (2002). Becoming a self-regulated learner: An overview. Theory into Practice, 41(2), 64-70. http://dx.doi.org/10.1207/s15430421tip4102_2

Zimmerman, B.J., \& Martinez-Pons M. (1990). Student differences in self-regulated learning: Relating grade, sex, and giftedness to self-efficacy and strategy use. Journal of Educational Psychology, 82(1), 51-59. http://dx.doi.org/10.1037/0022-0663.82.1.51

\section{Copyright Disclaimer}

Copyright for this article is retained by the author(s), with first publication rights granted to the journal.

This is an open-access article distributed under the terms and conditions of the Creative Commons Attribution license (http://creativecommons.org/licenses/by/3.0/). 